\title{
A new species of Myxobolus Bütschli, 1882 (Bivalvulida: Myxobolidae) infecting stratum spongiosum of the imperiled sicklefin redhorse, Moxostoma sp. (Cypriniformes: Catostomidae) from the Little Tennessee River, North Carolina, USA
}

\author{
Steven P. Ksepka ${ }^{1}$, Brian H. Hickson ${ }^{2}$, Nathan V. Whelan ${ }^{2,3}$ and Stephen A. Bullard ${ }^{1}$ \\ ${ }^{1}$ Aquatic Parasitology Laboratory, School of Fisheries, Aquaculture, and Aquatic Sciences, College of Agriculture, Auburn \\ University, Auburn, Alabama, USA; \\ ${ }^{2}$ Southeast Conservation Genetics Lab, Warm Springs Fish Technology Center, US Fish and Wildlife Service, Auburn, USA; \\ ${ }^{3}$ School of Fisheries, Aquaculture, and Aquatic Sciences, College of Agriculture, Auburn University, Auburn, Alabama, USA
}

\begin{abstract}
The sicklefin redhorse, Moxostoma sp. (Cypriniformes: Catostomidae), is an innominate imperiled catostomid endemic to the Hiwassee and Little Tennessee river basins, which has been restricted to a few tributaries of these systems by impoundments. During collections to propagate sicklefin redhorse for reintroduction, a myxozoan, described herein, was observed infecting sicklefin redhorse in the Little Tennessee River Basin, North Carolina. Myxobolus naylori Ksepka et Bullard sp. n. infects the stratum spongiosum covering the scales of sicklefin redhorse. Myxospores of the new species differ from all congeners by the combination of having a mucous envelope, intercapsular process, and sutural markings as well as lacking an iodinophilic vacuole in the sporoplasm. A phylogenetic analysis of the 18S rDNA gene recovered the new species in a polytomy with Myxobolus marumotoi Li et Sato, 2014 and a clade comprised of species of Myxobolus Bütschli, 1882; Thelohanellus Kudo, 1933, and Dicauda Hoffman et Walker, 1973. Histological sections of infected sicklefin redhorse skin revealed myxospores within a plasmodium in the stratum spongiosum dorsal to scales, encapsulated in collagen fibres, and associated with focal erosion of scales directly beneath the plasmodium; in some instances, the scale was perforated by the plasmodium. The specificity of the new species to sicklefin redhorse may make it a useful biological tag to differentiate sicklefin redhorse from morphologically similar species. The new species is the first parasite reported from sicklefin redhorse, a species of concern to the United States Fish and Wildlife Service. No species of Myxobolus has been reported from species of Moxostoma in the Southeast United States. As it was observed that Myxobolus minutus Rosser, Griffin, Quiniou, Alberson, Woodyard, Mischker, Greenway, Wise et Pote, 2016 is a primary junior homonym of Myxobolus minutus Nemeczek, 1911, we propose the replacement name Myxobolus diminutus (Rosser, Griffin, Quiniou, Alberson, Woodyard, Mischker, Greenway, Wise et Pote, 2016).
\end{abstract}

Keywords: Myxozoa, taxonomy, pathology, phylogeny

Myxobolus Bütschli, 1882 (Bivalvulida: Myxobolidae) is the most species-rich myxozoan genus, having $>800$ species that infect predominately freshwater fishes, have a worldwide distribution, and generally exhibit high host and tissue specificity (Eiras et al. 2005, Molnár and Eszterbauer 2015, Liu et al. 2019). Thirty-two species of Myxobolus infect suckers (Catostomidae), with most records sourcing from the Great Lakes of the United States and Southeast Canada (Table 1). Five nominal species of Myxobolus infect species of Moxostoma Rafinesque (Cypriniformes: Catostomidae): Myxobolus congesticus (Kudo, 1934), Myxobolus conspicuus (Kudo, 1929), Myxobolus gravidus Kudo, 1934, Myxobolus moxostomi Nigrelli, 1948, and Myxobolus vas- tus Kudo, 1934 (Table 1). Myxobolus congesticus infects the fins of the silver redhorse (Moxostoma anisurum [Rafinesque]) in the Rock River, Illinois (Kudo 1934). Myxobolus conspicuus was described infecting the dermis of the cranium of the smallmouth redhorse (Moxostoma breviceps [Cope]) in the Rock River, Illinois (Kudo 1929). It has subsequently been reported from that site of infection in smallmouth redhorse from the Fox River, Illinois, and shorthead redhorse (Moxostoma macroleptidotum [Lesueur]) from the St. Lawrence River and Lake Erie (Kudo 1934, Fantham et al. 1939, Dechtiar 1972). Myxobolus gravidus was described from the skin of the silver redhorse in the Fox River (Kudo 1934). Myxobolus moxostomi infects the epithelium of the

Address for correspondence: Steven P. Ksepka, Auburn University, 203 Swingle Hall, Auburn, AL 36849, USA. Phone: (802) 522-7682; Email: spk0014@auburn.edu 
shorthead redhorse from the New York Aquarium (Nigrelli 1948), and M. vastus infects the skin of shorthead redhorse from the Fox River (Kudo 1934). No species of Myxobolus has been reported from a species of Moxostoma in the Southeast United States.

Catostomids are almost entirely endemic to North America: the only exception being the Chinese high-fin banded shark (Myxocyprinus asiaticus [Bleeker] [Cypriniformes: Catostomidae]) that is endemic to Southeast Asia (Barton and Bond 2006). Moxostoma consists of 22 species endemic to North America (Fricke et al. 2019). Although most of these are relatively common and abundant throughout their range, several Moxostoma spp. are endemic to the southeastern USA. The robust redhorse (Moxostoma robustum [Cope]) is endemic to three river drainages in North Carolina and Georgia and was previously thought to be extinct. However, it was rediscovered in the 1990's and is currently listed as endangered in Georgia and North Carolina (Walsh et al. 1998, Peterson et al. 2013).

The sicklefin redhorse (Moxostoma sp.) is endemic to the Hiwassee and Little Tennessee river basins and most closely resembles the sympatric river redhorse (Moxostoma carinatum [Cope]) but can be differentiated by the placement of the breeding tubercles and presence of elongated dorsal fin rays (Favrot and Kwak 2018, Moyer et al. 2019). Habitat fragmentation has limited the range of the sicklefin redhorse to a few tributaries within these river basins; however, collection records indicate the sicklefin redhorse used to inhabit the majority of rivers in the Blue Ridge portion of these river basins (United States Fish and Wildlife Service 2020)

The United States Fish and Wildlife Service (USFWS) has ongoing projects to monitor populations of this species throughout its range and to propagate it for reintroduction into its historical habitat, which are currently focused on reintroducing sicklefin redhorse above impoundments in the Oconaluftee and Tuckasegee rivers (Little Tennessee River Basin) (Moyer et al. 2009, United States Fish and Wildlife Service 2020). As such, information about the specific taxonomic identity, pathological effects, and life cycles of the parasites and potential pathogens of these fishes are relevant to biosecurity associated with these planned stock enhancement activities.

The recent discovery of the causative agent of salmonid whirling disease in the southeastern United States (Ruiz et al. 2017) has raised awareness about the critical importance of conventional and molecular diagnostic approaches to identify species of Myxobolus. Based upon light microscopy of myxospores and histological sections of infected host tissue, we herein describe a new species of Myxobolus from the sicklefin redhorse. The new species is the sixth species of Myxobolus reported from a species of Moxostoma, the first reported from a species of Moxostoma in the Southeast USA, and the first parasite reported from the sicklefin redhorse.

\section{MATERIALS AND METHODS}

On 26 June 2018, myxospores consistent with a species of Myxobolus were excised from the skin of two sicklefin red- horses within a closed recirculating aquaculture system at the Warm Springs National Fish Hatchery, Warm Springs, Georgia. These fish were sourced from the Oconaluftee River (35.446329, -83.382937), Little Tennessee River Basin, North Carolina. Myxospores were fixed in $10 \%$ neutral buffered formalin (NBF) for morphology or preserved in $95 \%$ ethanol for DNA extraction and shipped to the Aquatic Parasitology Laboratory at Auburn University.

After discovering the infection in the captive fish, we initiated field efforts to obtain additional conspecific myxospores for morphology and nucleotide analysis by non-lethal sampling, i.e., biopsy of infected scales and adjacent skin. A total of 136 sicklefin redhorses were collected from four riverine sites in North Carolina and Georgia during April through May 2019: 25 from Brasstown Creek (34.981111, -83.887806), Hiwassee River Basin, Georgia (9-12 April 2019); 42 from Valley River (35.190100, -83.967000), Hiwassee River Basin (29 April-3 May 2019); 46 from Oconaluftee River (35.446329, -83.382937), Little Tennessee River Basin (7-8 May 2019); and 23 from Tuckasegee River (35.363800, -83.245700), Little Tennessee River Basin (9 May 2019). All sicklefin redhorse were identified in the field by the presence of elongated dorsal fin rays and the placement of breeding tubercles. Any fish that could not be confidently identified was not sampled. After collection, each fish was measured ( $\mathrm{mm}$ ), weighed (g), tagged, examined for infection (biopsied or not), and released. Infected scales were excised with fine forceps and plasmodia were parsed equally in $10 \% \mathrm{NBF}$ and $95 \%$ ethanol for morphology and DNA extraction, respectively.

Myxospore measurements were based on wet mounted, fresh, formalin-fixed myxospores using a $63 \times$ oil immersion objective and a $1.6 \times$ magnification changer. All measurements are reported in micrometres unless otherwise indicated. Lugol's iodine and India ink were used to stain the iodinophilic vacuole and mucous envelope, respectively (Lom and Arthur 1989). To illustrate myxospores they were vortexed to suspend myxospores before a drop of this suspension was cover-slipped, inverted, and placed onto a thin layer of $1 \%$ agar (Lom 1969). Illustrations were made using a $100 \times$ oil immersion objective on an Olympus BX51 compound scope equipped with $1.6 \times$ magnifier, DIC, and drawing tube.

After fixation, formalin-fixed, infected scales were rinsed in distilled water for two hours, decalcified in EDTA for one month, dehydrated in an ethanol series, embedded in paraffin, sectioned at $4 \mu \mathrm{m}$, and stained with Harris's hematoxylin and eosin (Luna 1968). Thirty slides were cut from each portion yielding $>180$ sections on 60 slides.

DNA was extracted from one microscopically/morphologically confirmed isolate of myxospores from each locality (Oconaluftee River and Tuckasegee River), each isolate consisted of myxospores from a single plasmodium, using the DNeasy Blood \& Tissue kit (Qiagen) according to the manufacturer's protocol. Two replicates were sequenced to identify any potential variability in the 18S rRNA gene. DNA concentration was measured using a NanoDrop-1000 spectrophotometer (Thermo Scientific, Nanodrop Technologies), diluted to $20 \mathrm{ng} / \mu \mathrm{l}$, and stored at $-20^{\circ} \mathrm{C}$. A 1,651 and 1,669 base pair fragment of the $18 \mathrm{~s}$ (rDNA) was amplified using primers M153-F (5'-CATTGGATAACCGTGGGAAATCT-3') and M2192-R (5'-TAGTAGCGACGGGCGGTGT-3') (Ksepka et al. 2019, 2020). 
PCR amplification used the following thermocycler parameters: initial denaturation step of $95 \mathrm{C}$ for four min, followed by 35 cycles of $95 \mathrm{C}$ for $30 \mathrm{~s}, 62 \mathrm{C}$ for $30 \mathrm{~s}$, and $72 \mathrm{C}$ for one min, with a final extension step of $72 \mathrm{C}$ for four min. Additionally, two sequencing primers M473-F (5'-GCTTGAGAAWCGGCTACCAC-3') and M1480-R (5'-GTGGTGCCCTTCCGTCAATTCC -3 ') were used to improve sequencing coverage (Ksepka et al. 2019, 2020). DNA sequencing was performed by ACGT incorporated (Wheeling, IL). Chromatograms were proofread by eye and assembled based on sequence overlap in Geneious version 2019.2.3 (http://www.geneious.com). Due to uneven sequencing and trimming of ambiguous base pairs at the 5' and 3' end of sequences, resulting sequences for the new species were 1,651 and 1,669 base pairs in length.

Additional taxon selection for phylogenetic analysis was based on a recent phylogenetic review of the Myxobolidae, which prioritised sequences $>1,300$ nucleotides tethered to a morphological diagnosis and included 74 species of the Myxobolidae from "clade E" of Zhang et al. (2019), all available sequences of Myxobolus spp. infecting catostomids, four species of Henneguya Thélohan, 1892 (Bivalvulida: Myxobolidae), and three species of Myxidiidae as an outgroup (Zhang et al. 2019). Sequences were aligned using MAFFT using an E-INS-i alignment strategy with a maxiterate value of 1,000 in Geneious version 2019.2.3 (Katoh and Standley, 2013). The alignment was trimmed to the length of sequences presented herein $(1,867$ base pairs $)$ to minimise missing data at the 5' and 3' end of the alignment. JModelTest2 version 2.1.10 selected the best-fit models of nucleotide substitution based on Bayesian information criteria (Darriba et al. 2012). Bayesian inference (BI) was performed in MrBayes version 3.2.5 (Ronquist and Huelsenbech 2003) using substitution model averaging (nst=mixed) and a gamma distribution to model rateheterogeneity. Defaults were used in all other parameters. Three runs with four Metropolis-coupled chains were run for 5,000,000 generations. Stationarity was checked in Tracer 1.7 (Rambaut et al. 2018) and an appropriate burn-in of $25 \%$ of generations was determined. Evidence of convergence was further checked with the "sump" command in MrBayes. All parameters had a potential scale reduction factor of 1.00. A majority rule consensus tree of the post burn-in posterior distribution was generated with the sumt command in MrBayes. The phylogenetic tree was visualised in FigTree v1.4.3 (Rambaut et al. 2014) and rendered for publication with Adobe Illustrator (Adobe Systems).

\section{DESCRIPTION}

Myxobolus naylori Ksepka et Bullard sp. n. Figs. 1-3 Zoobank number for article: urn:lsid:zoobank.org:pub:12BECF78-124E427E-9802-D220093DF8AB

Diagnosis of myxospores (based on 52 myxospores using differential interference contrast microscopy [25 stained with Lugol's iodine; 12 stained with India ink]; USNM coll. Nos. 1618813-1618818): Myxospore comprising 2 smooth symmetrical valves juxtaposed at sutural rim, 2 polar capsules, and sporoplasm; myxospore ellipsoid, 10.0-12.0 (mean $\pm \mathrm{SD}=10.8 \pm 0.6 ; \mathrm{N}=52$ ) long (Fig. 2A-C), 7.0-9.0 (8.2 $\pm 0.6 ; 38)$ wide (Fig. 2A-C), $5.0-6.0(5.5 \pm 0.5 ; 14)$ thick (Fig. 2D); sutural rim with prominent seam (Fig. 2D), 1.0 (39) thick (lateral margin in frontal view) (Fig. 2A-C), 1.0 (39) thick (posterior margin in frontal view) (Fig. 2A-C), without flanking lateral ridges (sutural), 1.0-9.0 $(5.0 \pm 2.0 ; 38)$ sutural markings; polar capsules equal (Fig. 2A-C), clavate (Fig. 2A-C), 4.0-6.0 $(4.9 \pm 0.6 ; 76)$ long (Fig. 2A-C), 2.0-3.0 (2.9 $\pm 0.2 ; 76)$ wide (Fig. 2A-C), with 7-10 polar filament coils (Fig. 2AC); sporoplasm lacking iodinophilic vacuole (Fig. 2A-C), having 2 nuclei (Fig. $2 \mathrm{~A}-\mathrm{C}) ; 1-2(1.8 \pm 0.4 ; 12)$ thick mucous envelope prominent on the rounded posterior margin (Fig. 2A-C).

Type and only reported host: Moxostoma sp. (Cypriniformes: Catostomidae), sicklefin redhorse.

Type locality: Oconaluftee River (35.446329, -83.382937), Little Tennessee River Basin, North Carolina.

Other localities: Tuckasegee River (35.363800, -83.245700), Little Tennessee River Basin, North Carolina.

Specimens deposited: Myxospores of M. naylori fixed in 10\% NBF (1 vial; syntype; USNM 1618813), and within paraffin sections (4 slides; syntypes; USNM 16188141618818); GenBank No. (18S: MN99711-MN99712).

Site in host: Intercellular plasmodia infecting the stratum spongiosum covering scales.

Prevalence: Myxospores were detected in 15 of 46 (prevalence $=33 \%$ ) sicklefin redhorses collected from the Oconaluftee River (35.446329, -83.382937), Little Tennessee River Basin, North Carolina and 2 of 23 (prevalence $=9 \%$ ) sicklefin redhorses collected from the Tuckasegee River (35.363800, -83.245700), Little Tennessee River Basin, North Carolina.

Et y m o log y: The specific epithet "naylori” honors Mr. Kenneth Joseph Naylor, SPK's friend, whose influence helped cultivate SPK's interest in biology.

Differential diagnosis: The myxospore of the new species differs from those of its 32 congeners infecting catostomids by dimensions and the polar filament count as well as by the presence of a mucous envelope, sutural markings, and intercapsular process. Further, the new species lacks an iodinophilic vacuole (Table 1). Of those 32 species, the myxospore of the new species differs from all but four $(M$. congesticus, M. conspicuus, Myxobolus ellipticoides [Fantham, Porter et Richardson, 1939], and Myxobolus subcircularis Fantham, Porter et Richardson, 1939) by myxospore dimensions and polar filament coil number (Table 1). Of those, the myxospore of the new species differs from that of $M$. congesticus and $M$. conspicuous by having a mucous envelope and intercapsular process as well as by lacking an iodinophilic vacuole. The myxospore of the new species differs from that of $M$. ellipticoides by having a mucous envelope, sutural markings, and an intercapsular process. The myxospore of the new species differs from that of $M$. subcircularis by having a mucous envelope, sutural markings, and intercapsular process as well as by lacking an iodinophilic vacuole (Fig. 2A-C).

A total of 17 species of Myxobolus that infect non-catostomid intermediate hosts have overlapping myxospore measurements with the new species (i.e. Myxobolus clariae Hemananda, Mohilal, Bandyopadhyay et Mitra, 2009, Myxobolus corneus Cone, Horner et Hoffman, 1990, Myxobolus gallaicus Iglesias, Parama, Alvarez, Leiro et Sanmartin, 2001, Myxobolus hyderabadense [Lalitha Kumari, 

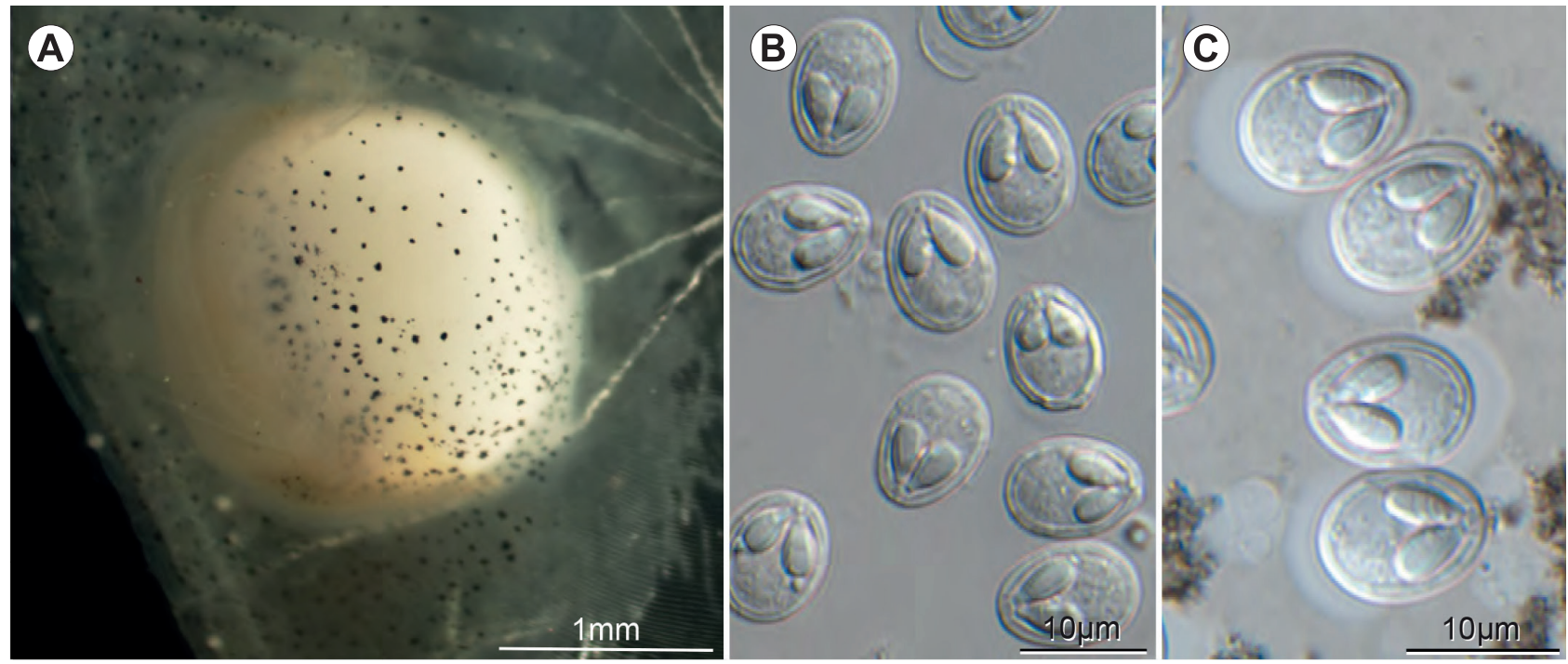

Fig. 1. A - sicklefin redhorse, Moxostoma sp. (Cypriniformes: Catostomidae) scale infected with a plasmodium of Myxobolus naylori Ksepka et Bullard sp. n. (Bivalvulida: Myxobolidae) from the Oconaluftee River, Little Tennessee River Basin, North Carolina; B Myxospores of Myxobolus naylori Ksepka et Bullard sp. n. (Bivalvulida: Myxobolidae) collected from sicklefin redhorse, Moxostoma sp. (Cypriniformes: Catostomidae) from Oconaluftee River, Little Tennessee River Basin, North Carolina; differential interference contrast optical components; in water; $\mathbf{C}$ - stained with India ink.

A

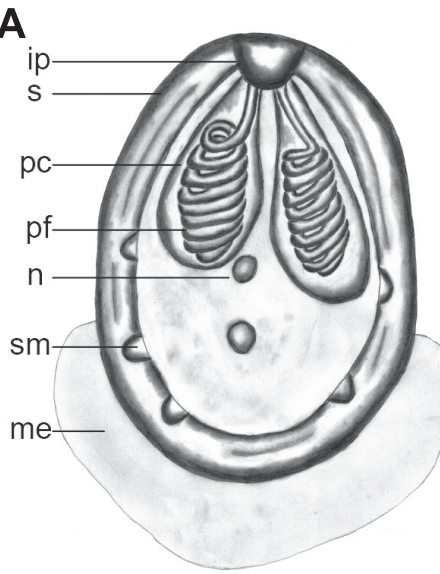

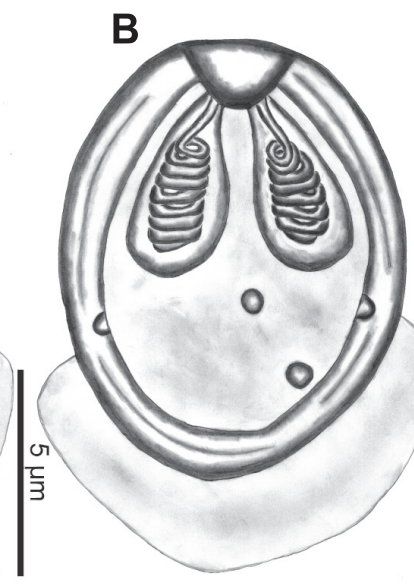
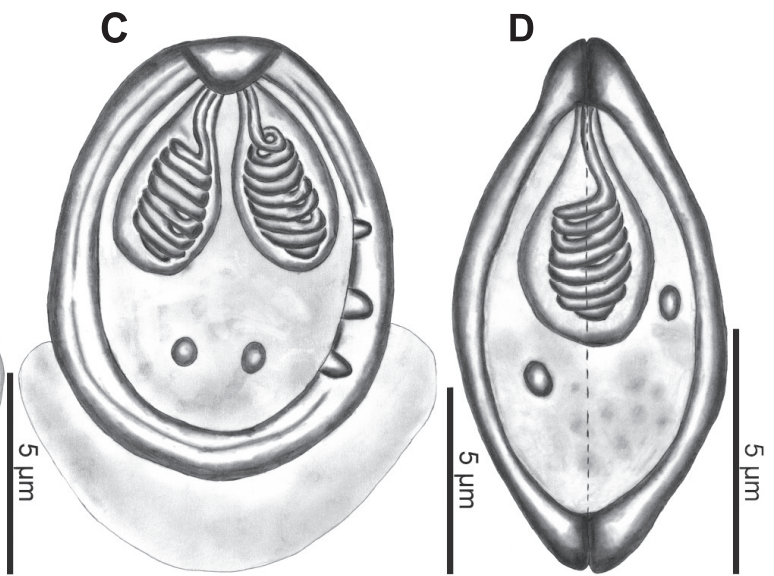

Fig. 2. Myxospores of Myxobolus naylori Ksepka et Bullard sp. n. (Bivalvulida: Myxobolidae) collected from sicklefin redhorse, Moxostoma sp. (Cypriniformes: Catostomidae) from Oconaluftee River, Little Tennessee River Basin, North Carolina. A-C - frontal view; D - sutural view. Abbrevation: sr - sutural rim; pc - polar capsule; pf - polar filaments; me - mucous envelope; sm - sutural markings, ip - intercapsular process; $\mathrm{n}-$ nuclei $(\mathrm{n})$. Scale bars $=5 \mu \mathrm{m}$.

1969], Myxobolus irinae Daniyarov, 1975, Myxobolus kalarfi [Kalantan et Arfin, 1991], Myxobolus leshanensis Ma et Zhao, 1992, Myxobolus macrocapsularis Reuss, 1906, Myxobolus mongolicus Pronin, 1973, Myxobolus naffari Abdel-Ghaffar, Ibraheim, Bashtar et Ali, 1998, Myxobolus njoyai Nchoutpouen et Fomena, 2011, Myxobolus percarinae Iskov et Karatev, 1982, Myxobolus smithi Salim et Desser, 2000, Myxobolus squamae Keysselitz, 1908, Myxobolus strelkovi Kostarev et Kulemina, 1971, Myxobolus zhujiangensis [Chen et Zhou, 1998], and Myxobolus zilli Sakiti, Blanc, Marques et Bouix, 1991) (Table 1).

The presence of sutural markings differentiates the new species from $M$. clariae, $M$. hyderabadense, $M$. kalarfi, $M$. macrocapsularis, $M$. naffari, $M$. njoyai, $M$. strelkovi, and M. zhujiangensis. The remaining eight species of Myxobo- lus infecting non-catostomids (M. corneus, M. gallaicus, M. irinae, M. leshanensis, M. mongolicus, M. percarinae, M. smithi, and M. squamae) have sutural markings and, with exception to M. corneus, are distinct from the new species by lacking an iodinophilic vacuole. The myxospore of the new species differs from that of $M$. corneus by having a mucous envelope (Fig. 2A-C).

While reviewing Myxobolus spp. that infect catostomids, it was observed that Myxobolus minutus Rosser, Griffin, Quiniou, Alberson, Woodyard, Mischker, Greenway, Wise et Pote, 2016 is a primary junior homonym of Myxobolus minutus Nemeczek, 1911 (Nemeczek 1911, Rosser et al. 2016). Per the code of International Code of Zoological Nomenclature (ICZN) article 53.3, two taxa erected within a genus with the same specific epithet constitutes primary ho- 

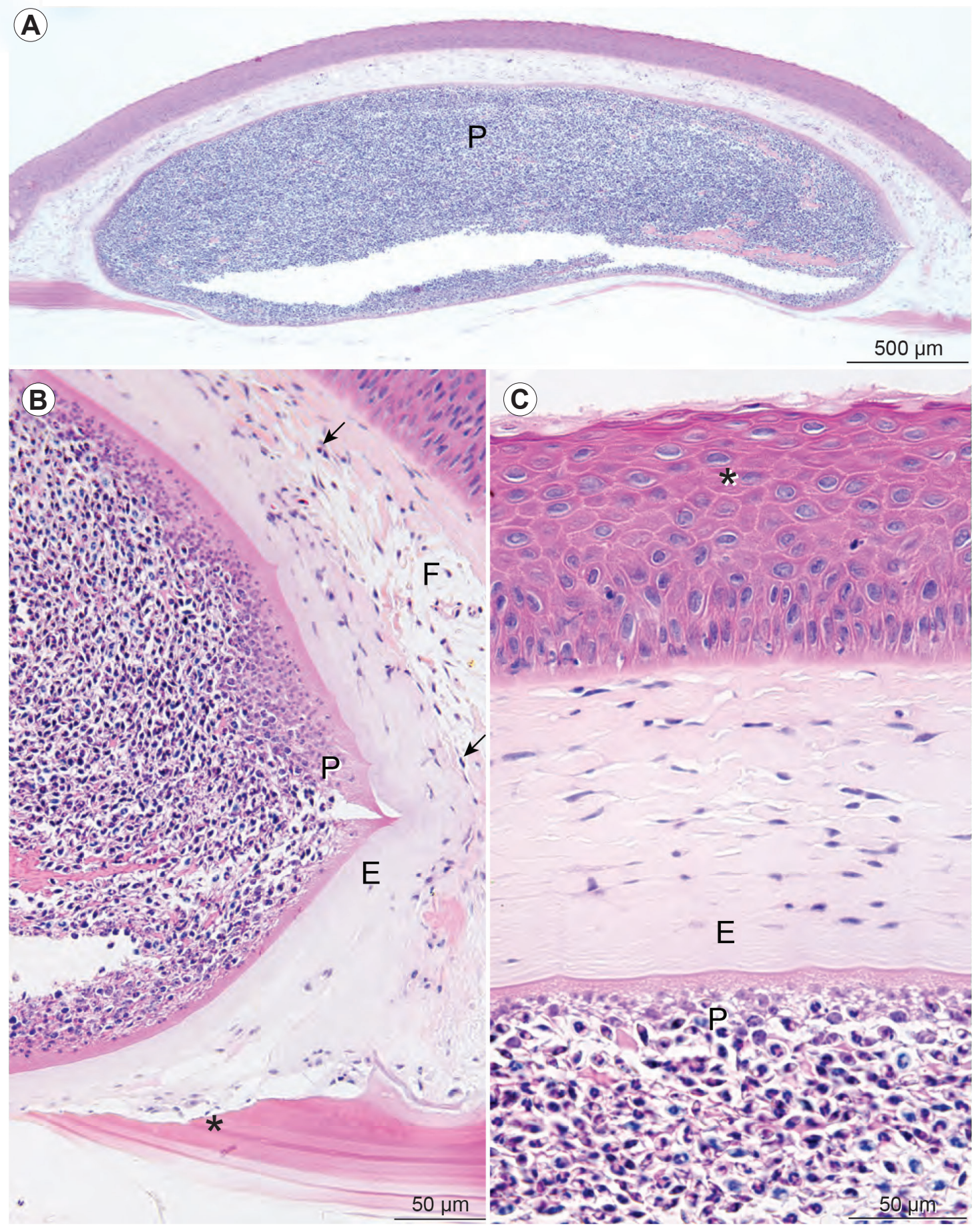

Fig. 3. Transverse histological sections (hematoxylin and eosin) of sicklefin redhorse, Moxostoma sp. (Cypriniformes: Catostomidae) scales infected with Myxobolus naylori Ksepka et Bullard sp. n. (Bivalvulida: Myxobolidae). A - infected stratum spongiosum showing plasmodia of myxospores (P); B - infected stratum spongiosum showing host encapsulation (E), scale loss (*), lymphocytic inflammatory infiltrates (arrows), and proliferating fibroblasts (F) associated with plasmodium (P); $\mathbf{C}$ - infected stratum spongiosum showing host encapsulation (E) and absence of mucous producing cells $\left(^{*}\right)$ associated with plasmodium.

monymy. Per ICZN articles 60.1 and 60.3, the junior homonym must be rejected and replaced with an available substitute name (Ride et al. 1999). We consulted with two of the taxonomic authorities of the latter proposed "M. minutus" (Graham Rosser, Mississippi State University, Starkville, Mississippi, and Matthew Griffin, Mississippi State University, Stoneville, Mississippi), who agreed with our replacement name, Myxobolus diminutus (Rosser, Griffin, Quini- ou, Alberson, Woodyard, Mischker, Greenway, Wise et Pote, 2016) nom. nov., for this taxon. This satisfies the ICZN and maintains the original etymology regarding the small size of the myxospores (Rosser et al. 2016).

\section{Phylogenetic analysis}

The two $18 \mathrm{~S}$ sequence fragments generated for the new species of Myxobolus comprised 1,867 base pairs after 


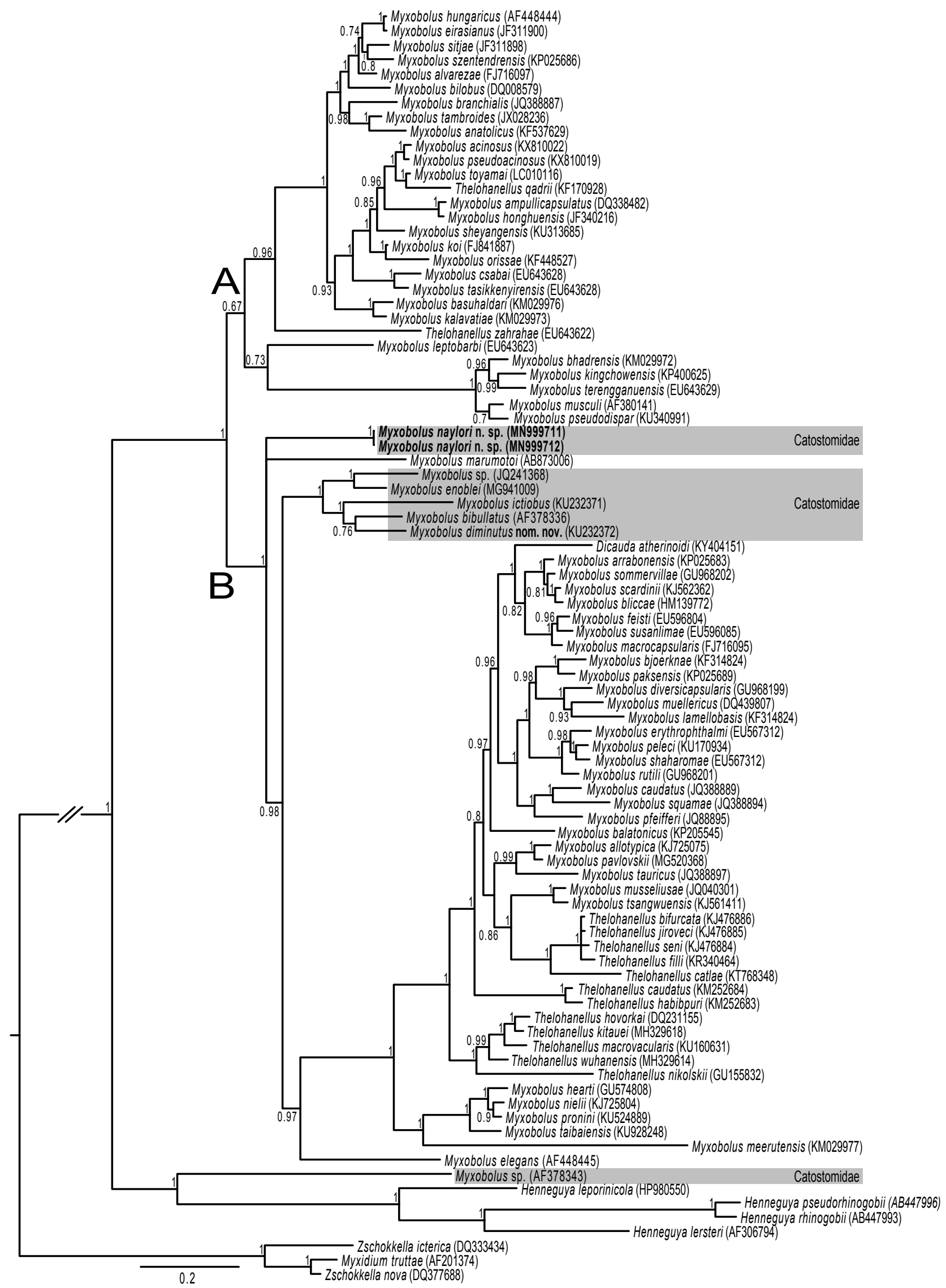

Fig. 4. Phylogenetic relationships of species of Myxobolidae infecting catostomids, cyprinids, and genetically similar species to $M y x-$ obolus naylori Ksepka et Bullard sp. n. (Bivalvulida: Myxobolidae) reconstructed with the 18S rRNA gene using Bayesian inference. Scale bar is in substitutions per site. New species in bold. Myxobolus spp. infecting catostomids boxed in grey. 


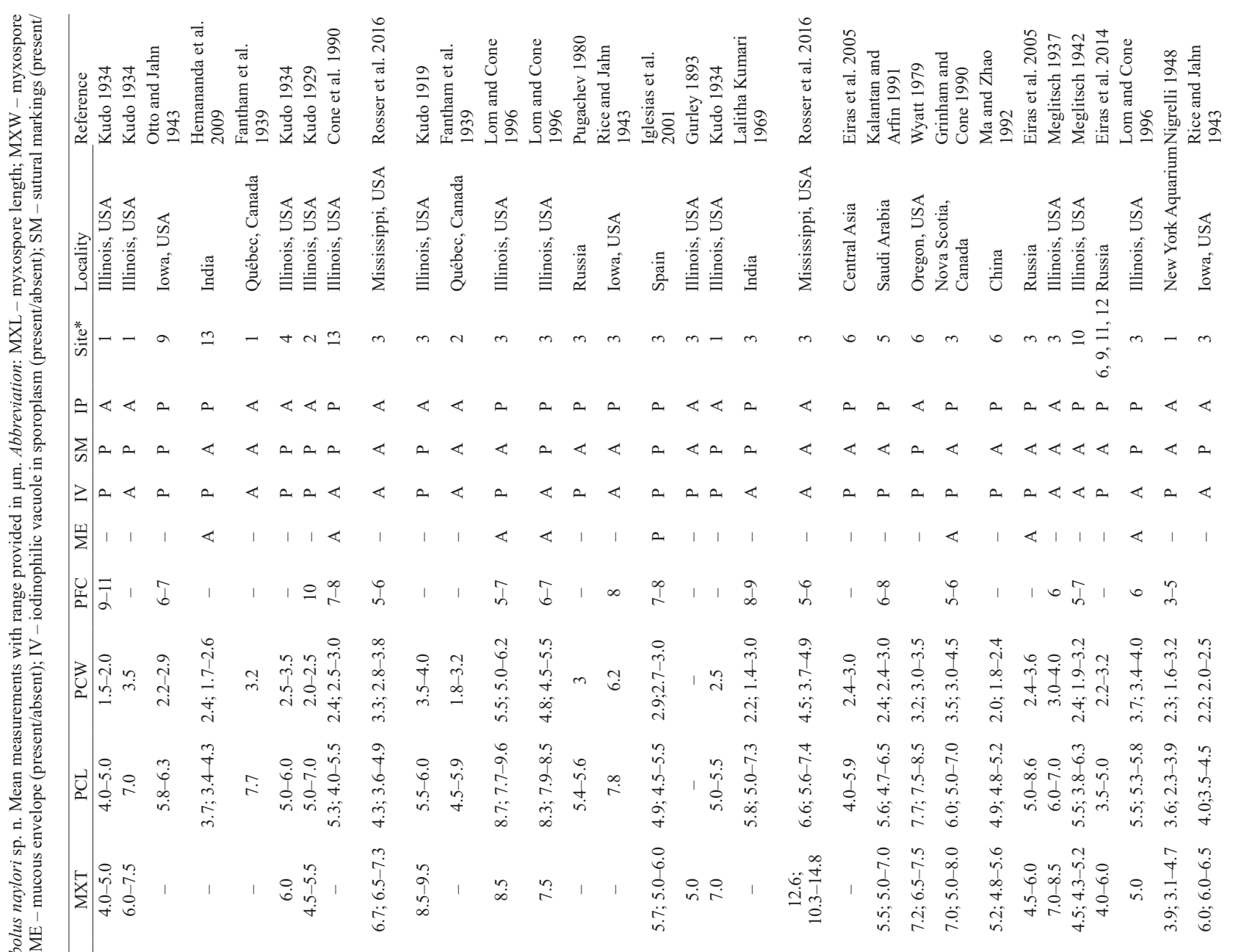

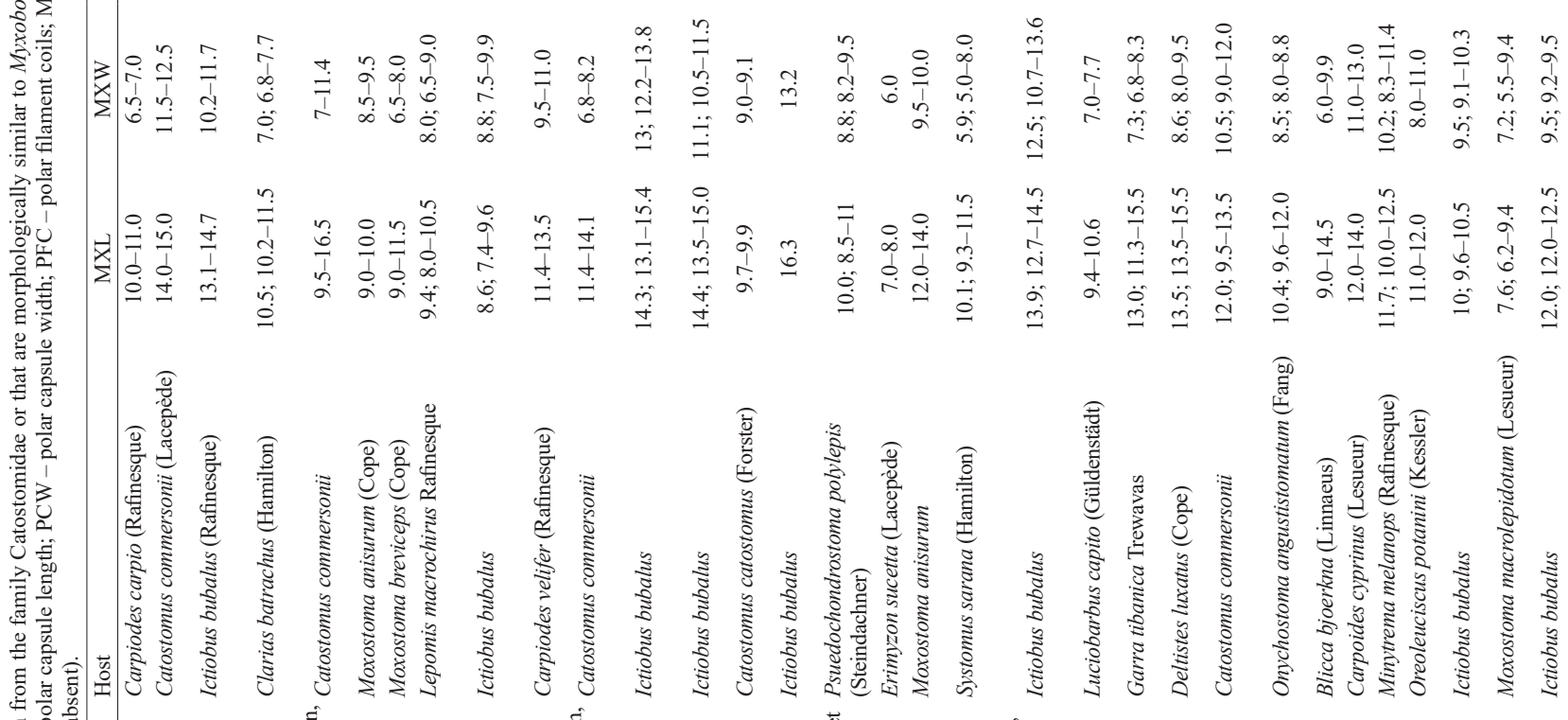

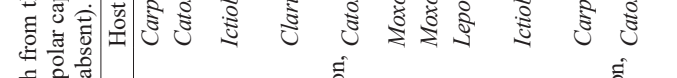




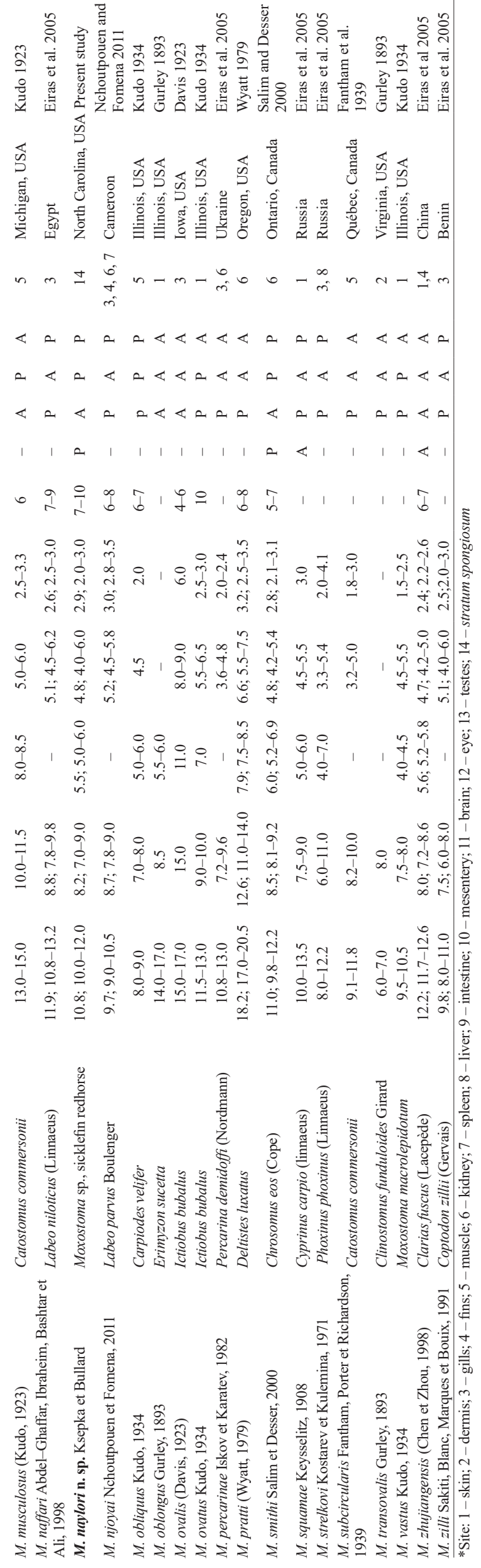

alignment and were identical. We recovered two well-supported clades: (A) 27 species of Myxobolus and two species of Thelohanellus Kudo, 1933 (Bivalvulida: Myxobolidae) and (B) 38 species of Myxobolus (including the new species), 12 species of Thelohanellus, and one species of Dicauda Hoffman et Walker, 1973 (Bivalvulida: Myxobolidae) (Fig. 4). Consistent with Liu et al. (2019), Myxobolus spp. that infect catostomids were recovered paraphyletic (Fig. 4). The new species was recovered as a distinct lineage within clade B, but was part of a polytomy with $M y x-$ obolus marumotoi Li et Sato, 2014, which infects the muscle of the dark sleeper (Odontobutis obscura [Temminck et Schlegel] [Gobiiformes: Odontobutidae]), and a clade comprising the remainder of clade B (Fig. 4). The uncertain placement of the new species may be a result of undersampling of Myxobolus spp. infecting catostomids and odontobutids, which are represented only by seven and one species, respectively, in contrast to Myxobolus spp. infecting cyprinids, which are represented by 57 species. Future studies to illuminate the diversity of species of Myxobolus infecting catostomids and odontobutids may provide better placement of the new species in phylogenetic analyses.

\section{Histopathology}

Plasmodia (ellipsoid in cross section) of Myxobolus naylori sp. n. were intercellular and infected the connective tissue of the stratum spongiosum of sicklefin redhorse skin. Myxospore development in the plasmodium was synchronous, with mature myxospores occupying almost the entire volume of the plasmodium (Fig. 3A). In both infected scales, plasmodia were encapsulated by a lightly eosinophilic layer of densely packed type I collagen fibres with active fibroblasts and sparse lymphocytic inflammatory infiltrates on the periphery of the encapsulation (Fig. 3B,C). Lateral to the plasmodia were regions of loosely packed proliferating fibroblasts (Fig. 3B). Scales beneath plasmodia showed varying degrees of erosion ranging from a marked thinning of the scale to a complete loss of the area of the scale beneath the plasmodium (Fig. 3A,B). Goblet and alarm substance cells were absent from the epithelium anterior to plasmodia (Fig. 3A,C). In fish infected with up to 14 plasmodia, no scale was observed having $>1$ plasmodium.

\section{DISCUSSION}

Particular parasite infections have been proposed as effective biological tags (MacKenzie 2002, Marcogliese and Jacobson 2014), and it is not uncommon to encounter proposals by parasitologists or fisheries biologists to use this or that parasite as a marker ("tag") that helps a biologist identify to what species or population the host belongs. However, there are many pitfalls to this practice (MacKenzie and Abaunza 2005). Parasites suitable for use as biological tags should (i) persist in host for a long period of time, (ii) exhibit a high degree of host specificity (ideally strict specificity; the parasite does not infect another host), (iii) be benign (non-pathogenic), and (iv) be relatively easy to identify in the field or easily observed as an ectoparasite (MacKenzie et al. 2013). Some myxozoans meet these criteria and represent a promising group of parasites to be 
used as biological tags because they exhibit high host specificity and can reside in their host for many years (Cantatore et al. 2016). As such, a number of myxozoans have been used as biological tags in stock assessments (Catalano et al. 2014, Marcogliese and Jacobson 2014). Myxobolus arcticus (Pugachev et Khokhlov, 1979) has been used to assess homing precision and natal origin of Chinook salmon (Oncorhynchus tshawytscha [Walbaum] [Salmoniformes: Salmonidae]) (Quinn et al. 1987). Kudoa nova Naidenova, 1975 (Multivalvulida: Kudoidae) has been used to differentiate stocks of Atlantic horse mackerel (Trachurus trachurus [Linnaeus] [Carangiformes: Carangidae]) (MacKenzie et al. 2008). While many species of Myxobolus are extremely morphologically similar, the new species' unique combination of possessing a mucous envelope, intercapsular process, sutural markings, and lacking an iodinophilic vacuole in the sporoplasm makes it relatively simple to identify, especially given the minute size of the myxospore. Although the plasmodia reside beneath the epithelium, their large size makes them readily apparent (presenting as an ectoparasite) such that no dissection of, and no killing of, the host is required to identify infections. In specific, the new species represents a potential biological tag for the sicklefin redhorse in the Little Tennessee River Basin due to its likely high level of host specificity (infecting only sicklefin redhorse) in that drainage basin. It is worth noting that it is possible the new species could infect closely related Moxostoma spp. However, after the initial detection in 2018 personnel were screening all Moxostoma spp. collected for infections and did not observe plasmodia on the body surface of any other species of Moxostoma suggesting the new species is specific to sicklefin redhorse. This could be useful in differentiating the sicklefin redhorse from the river redhorse, which inhabits the same system and can be difficult to differentiate from the sicklefin redhorse, particularly if the dorsal fin, the primary morphological difference between the species, is damaged.

No species of Myxobolus has been reported as a pathogen of a wild catostomid. The lesion we report herein is minor and probably benign to the overall health of infected sicklefin redhorses. Conversely, obviously, several myxozoans are pathogenic if infecting hosts outside of their native range (Bartholomew and Reno 2002, Molnár 2002). For example, Myxobolus cerebralis (Bütschli, 1882), the causative agent of whirling disease, was introduced to North America from Europe (Bartholomew and Reno 2002) and is non-pathogenic to brown trout (Salmo trutta Linnaeus) in Europe. In North America, M. cerebralis led to mortality of wild and cultured salmonids and remains one of the most important salmonid pathogens in North America (Thompson et al. 1999, Bartholomew and Reno 2002). Thelohanellus nikolskii Akhmerov, 1954 was introduced from Asia to Europe with infected grass carp (Ctenopharynodon idella [Valenciennes]) (Molnár 2002). Outside of its native range $T$. nikolskii forms clusters of plasmodia on the fins, impairing fin development, of common carp (Cyprinus carpio Linnaeus) representing one of the most common diseases of carp in Hungary (Molnár 1982, 2002). As the new species was not detected in the 41 fish from the Hiwassee River Basin, previous sicklefin redhorse survey work in the Hiwassee River Basin have not resulted in reports of infections by Myxobolus, and breeding and reintroduction/stock enhancement efforts are ongoing, it is important to consider the new species as a potential pathogen if introduced to the Hiwassee River Basin population or into a culture setting.

Acknowledgements. We thank Dave Matthews (Tennessee Valley Authority), Jason Mays (USFWS), Luke Etchison (North Carolina Wildlife Resources Commission [NCWRC]), Dylan Owensby (NCWRC), Mike Abney (Duke Energy), Ryan Heise (Duke Energy), Brett Albanese (Georgia Department of Natural Resources), Caleb Hickman (Eastern Band of the Cherokee Indians), and Jaclyn Zelko (USFWS) for helping collect infected sicklefin redhorse. This project was supported by research grants from the Alabama Agricultural Research Station, North Carolina Wildlife Resources Commission, United States Fish and Wildlife Service, and the United States Gulf States Marine Fisheries Commission Aquatic Nuisance Species Program. The findings and conclusion are those of the authors and do not necessarily represent the views of the Unites States Fish and Wildlife Service.

\section{REFERENCES}

Bartholomew J.L., Reno P.W. 2002: The history and dissemination of whirling disease. American Fisheries Society Symposium 26: 1-22.

Cantatore D.M.P., Irigoitia M.M., Holzer A.S., Timi J.T. 2016: Myxozoans as biological tags for stock identification of the argentine hake, Merluccius hubbsi (Gadiformes: Merlucciidae). Parasitology 143: 732-740.

Catalano S.R., Whittington I.D., Donnnellan S.C., GilLANDERS B.M. 2014: Parasites as biological tags to assess host population structure: guidelines, recent genetic advances and comments on a holistic approach. Int. J. Parasitol. Parasit. Wildl. 3: $220-226$.

Cone D.K., Horner R.W., Hoffman G.L. 1990: Description of Myxobolus corneus (Myxosporea): a new species from the eye of bluegill from Illinois. J. Aquat. Anim. Hlth. 2: 132-134.

Darriba D., Taboada G.L., Doallo R., Posada D. 2012: jModelTest 2: more models, new heuristics, and parallel computing. Nat. Methods 9: 772.
DAVIS H.S. 1923: Studies on sporulation and development of the cysts in a new species of myxosporidia, Lentospora ovalis. J. Morphol. 37: 425-455.

Dechtiar A.O. 1972: New parasite records for Lake Erie fish. Great Lakes Fisheries Commission Technical Report No. 17: $1-17$.

Eiras J.C., Molnár K., Lu Y.S. 2005: Synopsis of the species of Myxobolus Bütschli, 1882 (Myxozoa: Myxosporea: Myxobolidae). Syst. Parasitol. 61: 1-46.

Fantham H.B., Porter A., L. R. Richardson L.R. 1939: Some Myxosporidia found in certain freshwater fishes in Quebec province, Canada. Parasitology 31: 1-77.

FAVRot S.D., KwAK T.J. 2018: Behavior and reproductive biology of the sicklefin redhorse: an imperiled southern Appalachian Mountain fish. Trans. Am. Fish. Soc. 147: 204-222.

Fricke R., ESCHMEYeR W.N., VAN DER LAAN R. (EDS.) 2019: Eschmeyer's Catalog of Fishes. Available at: http://researchar- 
chive.calacademy.org/research/ichthyology/catalog/fishcatmain. asp. Accessed 8 September 2019.

Grinham T., Cone D.K. 1990: A review of species of Myxobolus (Myxosporea) parasitizing catostomid fishes, with a redescription of Myxobolus bibullatus (Kudo, 1934) n. comb. and description of Myxobolus lamellus n. sp. from Catostomus commersoni in Nova Scotia. Can. J. Zool. 68: 2290-2298.

Gurley M.D. 1893: On the classification of the Myxosporidia, a group of protozoan parasites infecting fishes. Bull. U.S. Fish. Comm. 11: 407-420.

Hemananda T., Mohilal N., Bandyopadhyay P.K., Mitra A.K. 2009: Two new myxosporidia (Myxozoa: Myxosporea) of the genus Myxobolus Bütschli, 1882 from the cornea of Clarias batrachus (Linnaeus, 1758) caught from a fish farm in India. North-Western J. Zool. 5: 165-169.

Iglesias R., Paramá A., Alvarez F., Leiro J., Sanmartin M.L. 2001: Myxobolid parasites infecting the gills of the Iberian nase, Chondrostoma polylepis (Steindachner), in Galicia (NW Spain), with a description of Myxobolus gallaicus sp. nov. J. Fish. Dis. 24: 125-134.

Kalantan A.M.N., Arfin M. 1991: Studies on Myxobolus garrai n. sp. (Myxozoa: Myxosporea) parasitizing Garra tibanica in Saudi-Arabia. Zool. Anz. 26: 261-266.

Katoh K., Standley D.M. 2013: MAFFT multiple sequence alignment software version 7: improvements in performance and usability. Mol. Biol. Evol. 30: 772-780.

Ksepka S.P., Rash J.M., Whelan N., Bullard S.A. 2019: A new species of Myxobolus (Myxozoa: Bivalvulida) infecting the medulla oblongata and nerve cord of brook trout Salvelinus fontinalis in southern Appalachia (New River, NC, USA). Parasitol. Res. 118: 3241-3252.

Ksepka S.P., Whelan N., Whipps C.M., Bullard S.A. 2020: A new species of Thelohanellus Kudo, 1933 (Myxozoa: Bivalvulida) infecting the skeletal muscle of blacktail shiner, Cyprinella venusta Girard, 1856 (Cypriniformes: Cyrpinidae) in the Chattahoochee River Basin, Georgia. J. Parasitol. 106: 350-359.

Kudo R. 1919: Studies on Myxosporidia. A synopsis of genera and species of Myxosporidia. Ill. Biol. Monogr. 5: 1-265.

KuDo R. 1929: Histozoic myxosporidia found in fresh-water fishes of Illinois, U.S.A. Arch. Protistenkd. 65: 364-378.

Kudo R. 1934. Studies on some protozoan parasites of fishes of Illinois. Ill. Biol. Monogr. 13: 7-44.

Lalitha Kumari P.S. 1969: Studies on parasitic Protozoa (Myxosporidia) of fresh water fishes of Andhra Pradesh, India. Riv. Parassitol. 30: 153-226.

Liv Y., Lövy A, Gu Z., Fiala I. 2019: Phylogeny of Myxobolidae (Myxozoa) and the evolution of myxospore appendages in the Myxobolus clade. Int. J. Parasitol. 49: 523-530.

Lom J. 1969: On a new taxonomic character in Myxosporidia, as demonstrated in descriptions of two new species of Myxobolus. Folia Parasitol. 16: 97-103.

Lom J., Arthur J.R. 1989: A guideline for the preparation of species descriptions in Myxosporea. J. Fish. Dis. 12: 151-156.

Lom J., Cone D.K. 1996: Myxosporeans infecting the gills of the bigmouth buffalo (Ictiobus bubalus) in Illinois, USA. Folia Parasitol. 43: 37-42.

LunA L.G. 1968: Manual of Histologic Staining Methods of the Armed Forces Institute of Pathology. Third edition. McGrawHill, New York, 258 pp.

Ma C.L., Zнао Y.J. 1993: [The parasitic myxosporidia of fresh-water fishes from the west region of Sichuan Province II. Six new species of the genus Myxobolus.] Acta Zootax. Sin. 18: 262-269. (In Chinese.)

MacKenzie K. 2002: Parasites as biological tags in population studies of marine organisms: an update. Parasitology 124: 153163

MacKenzie K., Abaunza B. 2005: Parasites as biological tags. In: S.X. Cadrin, L.A. Kerr, and S. Mariani (Eds.), Stock Identification Methods. Elsevier Academic Press, Cambridge, Massachusetts, pp. 185-203.
MacKenzie K., Brickle P. Hemmingsen W., George-Nascimento M. 2013: Parasites of hoki, Macruronus magellanicus, in the Southwest Atlantic and Southeast Pacific Oceans, with an assessment of their potential value as biological tags. Fish. Res. 145: $1-5$.

MacKenzie K., Campbell N., Mattiucci S., Ramos P., Pinto A.L., Aвaunza P. 2008: Parasites as biological tags for stock identification of Atlantic horse mackerel Trachurus trachurus L. Fish. Res. 89: 136-145.

Marcogliese D.J., Jacobson K.C. 2015: Parasites as biological tags of marine, freshwater and anadromous fishes in North America from the tropics to the arctic. Parasitology 142: 68-89.

Meglitsch P.A. 1937: On some new and known Myxosporidia of the fishes of Illinois. J. Parasitol. 23: 467-477.

Meglitsch P.A. 1942: Myxosoma microthesum n. sp. of Minytrema melanops. Trans. Am. Microsc. Soc. 61: 33-35.

MoLnÁR K. 1982: Biology and histopathology of Thelohanellus nikolskii Akhmerov, 1955 (Myxosporea, Myxozoa), a protozoan parasite of the common carp (Cyprinus carpio). Z. Parasitenkd. 68: 269-277.

MolnÁR K. 2002: Differences between the European carp (Cyprinus carpio carpio) and the coloured carp (Cyprinus carpio haemopterus) in the susceptibility to Thelohanellus nikolskii (Myxosporea) infection. Acta Vet. Hung. 50: 51-57.

Molnár K., Eszterbauer E. 2015: Specificity of infection sites in vertebrate hosts. In: B. Okamura, A. Gruhl and J.L. Bartholomew (Eds.), Myxozoan Evolution, Ecology and Development. Springer International Publishing, Cham, Switzerland, pp. 295-313.

Moyer G.R, Bohn S., Cantrell M., Williams A.S. 2019: Use of genetic data in a species status assessment of the sicklefin redhorse (Moxostoma sp.). Conserv. Genet. 20: 1175-1185.

Moyer G.R., Rousey J.D., Cantrell M.A. 2009: Genetic evaluation of a conservation hatchery program for reintroduction of sicklefin redhorse Moxostoma sp. in the Tuckasegee River, North Carolina. N. Am. J. Fish. Manag. 29: 1438-1443.

Nchoutpouen E., Fomena A. 2011: Description de trois espèces nouvelles de Myxobolus (Myxosporea: Myxobolidae) parasites de Labeo parvus Boulenger, 1902 (Cyprinidae) au Cameroun. J. Appl. Biosci. 38: 2508-2517.

NemeczeK A. 1911: Beiträge zur Kenntnis der Myxo und Microsporidien der Fischer. Arch. Protistenkd. 22: 143-169.

Nigrelli R.F. 1943: Causes of diseases and death of fishes in captivity. Zool. Sci. Contrib. N.Y. Zool. Soc. 28: 203-216.

Nigrelli R.F. 1948: Prickle cell hyperplasia in the snout of the redhorse sucker (Moxostoma aureolum) associated with an infection by the myxosporidian Myxobolus sp. nov. Zool. Sci. Contrib. N.Y. Zool. Soc. 33: 43-46.

Отто G.R., JАнN T.L. 1943. Internal myxosporidian infections of some fishes of the Okoboji region. Proc. Iowa Acad. Sci. 50: 323-335.

Peterson R.C., Jennings C.A., Peterson J.T. 2013: Relationships between river discharge and abundance of age 0 redhorses (Moxostoma spp.) in the Oconee River, Georgia, USA, with implications for robust redhorse. River Res. Appl. 29: 734-742.

Pugachev O.N. 1980: [Parasite fauna of the sucker (Catostomus catostomus) from the Kolyma River.] Parazitologiya 14: 511-513. (In Russian.)

Quinn T.P., Wood C.C., Margolis L., Riddell B.E., HyatT K.D. 1987: Homing in wild sockeye salmon (Oncorhynchus ner$k a$ ) populations as inferred from differences in parasite prevalence and allozyme allele frequencies. Can. J. Fish. Aquat. Sci. 44: 1963-1971.

Rambaut A., Drummond A.J., Xie D., Baele G., Suchard M.A. 2018: Posterior summarization in Bayesian phylogenetics using Tracer 1.7. Syst. Biol. 67: 901-904.

Rambaut A., Suchard M.A., Xie D., Drummond A.J. 2014: FigTree v1.4.3. Available from http://tree.bio.ed.ac.uk/software/ figtree. 
RICE V.J., JAHN T.L. 1943: Myxosporidian parasites from the gills of some fishes of the Okoboji region. Proc. Iowa Acad. Sci. 50: 313-321.

Ride W.D., Cogger H.G., Dupuis C, Kraus O., Minelli A., Thompson F.C., TubBs P.K. 1999: International Code of Zoological Nomenclature. Fourth edition. International Trust for Zoological Nomenclature, The Natural History Museum, London, United Kingdom.

Ronquist F., Huelsenbeck J.P. 2003: MrBayes 3: Bayesian phylogenetic inference under mixed models. Bioinformatics 19: $1572-1574$.

Rosser T.G., Griffin M.J. Quiniou S.M.A., Alberson N.R., Woodyard E.T., Mischke C.C., Greenway T.E. Wise D.J., Роте L.M. 2016: Myxobolus ictiobus n. sp. and Myxobolus minutus n. sp. (Cnidaria: Myxobolidae) from the gills of the smallmouth buffalo Ictiobus bubalus Rafinesque (Cypriniformes: Catostomidae). Syst. Parasitol. 93: 565-574.

Ruiz C.F., Rash J.M., Arias C.R., Besler D.A., Orélis-Ribeiro R., Womble M.R., Roberts J.R., Warren M.B., Ray C.L., LaFrentz S., Bullard S.A. 2017: Morphological and molecular confirmation of Myxobolus cerebralis myxospores infecting wild-caught and cultured trout in North Carolina (SE USA). Dis. Aquat. Org. 126: 185-198.
SAlim K.Y., DesSER S.S. 2000: Descriptions and phylogenetic systematics of Myxobolus spp. from cyprinids in Algonquin Park, Ontario. J. Euk. Microbiol. 47: 308-318.

Thompson K.G., Nehring R.B., Bowden D.C., Wygant T. 1999: Field exposure of seven species or subspecies of salmonids to Myxobolus cerebralis in the Colorado River. J. Aquat. Anim. H1th. 11: 312-329.

United States Fish and Wildlife Service (eds.) 2020: Sicklefin redhorse Moxostoma sp. Available at: https://www.fws.gov/ southeast/wildlife/fishes/sicklefin-redhorse/

Walsh S.J., Haney D.C., Timmerman C.M., Dorazio R.M. 1998: Physiological tolerances of juvenile robust redhorse, Moxostoma robustum: conservation implications for an imperiled species. Environ. Biol. Fishes 51: 429-444.

Wyatt E.J. 1979: Facieplatycauda pratti gen. n., sp. n. and two new species of Myxobolus (Myxosporidia). J. Protozool. 26: 47-51.

Zhang Z., LiU Y., Whipps C.M., Guo Q., Gu Z. 2019: Multiple evolutionary routes of the single polar capsule in Thelohanellus species (Myxozoa; Myxobolidae). Int. J. Parasitol. Parasit. Wildl. 8: 56-62.

Cite this article as: Ksepka S.P., Hickson B.H., Whelan N.V., Bullard S.A. 2020: A new species of Myxobolus Bütschli, 1882 (Bivalvulida: Myxobolidae) infecting stratum spongiosum of the imperiled sicklefin redhorse, Moxostoma sp. (Cypriniformes: Catostomidae) from the Little Tennessee River, North Carolina, USA. Folia Parasitol. 67: 030. 